Acest articol se citează:

Burzo, T., (2016/2018). Studiu privind agresivitatea și autonomia personală la militari și persoane civice. Studia Doctoralia. Psychology and Educational Science, 11-12, 74-89.

\title{
STUDIU PRIVIND AGRESIVITATEA ȘI AUTONOMIA PERSONALĂ LA MILITARI ȘI PERSOANE CIVILE
}

Tudor Burzo, Universitatea din București, Facultatea de Psihologie și Științele Educației E-mail: tudorburzo@gmail.com

\begin{abstract}
This study aims to analyze the possible differences between the level of aggression and of personal autonomy among samples of civilian and military personnel from Romania. This study was attended by 103 people, including a group of 50 active militaries and a second group of 53 civilians working in different sectors of the civilian environment.

The data obtained were quantitatively and qualitatively processed to accurately capture any identified differences. There were no statistically significant differences between the level of aggression and of personal autonomy in terms of military and civilians. However, differences have been identified in terms of a single dimension of personal autonomy, behavioral autonomy. Contrary to the stated hypothesis, the results indicate a higher level of behavioral autonomy in the military, compared to the civilians who participated to this study.
\end{abstract}

Keywords: agression, personal autonomy, behavioural autonomy, civil and military personnel.

\section{Introducere}

Capacitatea forțelor armate ale unei țări evidențiază atât nivelul de dezvoltare al țării respective, cât și particularitățile psihologice ale resursei umane de care țara în cauză beneficiază. În acest context procesul de selecție a militarilor este unul deosebit de complex, sistematizat și diversificat în funcție de specificul categoriei de forțe în 
care aceșia urmează să își desfășoare activitatea. De la evaluări medicale, la evaluări sportive și de cunoștințe specifice, procesul selecției are ca punct culminant evaluările psihologice aplicate pe mai multe paliere (teste care măsoară $\mathrm{IQ}$, chestionare care investighează diferite laturi ale personalității și susținerea unui interviu dirijat), neîncadrarea în standardele prestabilite însemnând excluderea din procesul de selecție.

Apreciind astfel cumulul probelor la care este supus un viitor miliar, se evidențiază modul în care beneficiarul (armata) caută un anumit profil care să se potrivească valorilor și principiilor promovate în cadrul ei, dar și specificului activății ce urmează a fi desfăşurată. Făcând referire la caracteristicile psihologice urmărite în procesul de selecție a militarilor, dat fiind specificul activității și responsabilității ierarhic piramidale - unde respectarea întocmai a ordinelor transmise, chiar dacă acestea contravin credințelor propri, și manifestarea unui comportament ofensiv agresiv atunci când superiorul o cere, capătă valențe de obligativitate - se remarcă o necesitate de cuantificare referitoare la nivelul de agresivitate și autonomie personală a militarilor care își desfășoară activitatea în diferite categorii de forțe luptătoare comparativ cu societatea civilă, ghidată de alt set de reguli de relaționare și alte pârghii motivaționale.

Prezenta lucrare își propune să ofere o perspectivă clară cititorului din punct de vedere al agresivității și autonomiei personale în contextul unor medii diferie, mediul cazon și cel civil, privite prin lentila psihologiei, știință care are în centrul său studiul psihicului, al proceselor și însușirilor psihice. Astfel, existența unor diferențe la nivelul constructelor vizate conturează pe de-o parte aspecte relevate despre profilul unui militar și, pe de altă parte. prezintă anumite caracterisitici ale unei subcategorii a populației inclusă la rândul său în societatea civilă. În această ordine de idei, influența mediului cazon asupra individului membru al societății civile și militar în același timp prezintă interes, mai ales în lipsa unor cercetări care să evidențieze acest lucru.

\section{Caracteristici ale mediului cazon}

Experiența dobândită pe parcursul anilor pre/postuniversitari în instituții de învățământ militar, licee și academii militare, este percepută 
adesea ca fiind un punct de turnură în viața tinerilor adolescenți, ale cărei influențe persistă pe tot parcursul vieții lor (Jackson, et al. 2012 apud Elder, Gimbel \& Ivie, 1991). Astfel, se desprinde existența unui sentiment răspândit conform căruia experiența militară obligă indivizii să socializeze și să se maturizeze (Jackson, et al. 2012 apud James, 1988).

Jackson și colaboratorii săi (2012) au descoperit că, mediul militar are o influență de durată asupra personalităților oamenilor într-un mod pe care puține alte experiențe îl fac, astfel accentul pus pe cultivarea spiritului de lucru în echipă este dat de riscul implicat în această activitate, mai ales pentru militarii din cadrul unei arme luptătoare (infanterie, cercetași, EOD etc.), întrucât aceștia sunt nevoiți să își încredințeze viața comandantului direct și reciproc camarazilor din subunitate.

Trăsăturile de personalitate ale militarilor constituie aspecte definitorii care îi influențiază pe aceștia să se înroleze în armată. Astfel, persoane $\mathrm{cu}$ un nivel de agreabilitate, nevrotism și deschidere la experiențe noi scăzut sunt predispuse să urmeze această carieră (Jackson et al., 2012). De asemenea, nu trebuie neglijată motivația dată de obținerea unui loc de muncă sigur, care se bucură, la nivelul societății, de un statut privilegiat și de venituri constante, de obicei peste media veniturilor salariale din țara respectivă.

O categorie aparte de militari sunt cei aflați în rezervă, aceștia situându-se în interiorul sistemului militar, făcând parte din acesta, însă ca parte integrată pe deplin din mediul civil. Prin rezerviști se înțelege acea categorie de forțe, care pe timp de pace, nu este implicată în mod activ în sistemul militar de apărare al țării, însă care poate fi rapid mobilizată în caz de situații urgente (Lomsky-Feder, Gazit \& Ben-Ari, 2008). La ora actuală conform surselor deschise România dispune de un număr aproximativ de 73.350 de militari activi și 79.900 de militari în rezervă, în condițiile în care la nivelul anului 2017 populația acestei țări, conform www.digi24.ro număra 19,63 milioane de persoane. Astfel, prin efectuarea unui calcul aritmetic, se observă că populația militarilor activi reprezintă $0,37 \%$ din populația României, procentul militarilor activi și în rezervă fiind de $0,78 \%$. 


\section{Impactul specificului activității desfăşurate asupra nivelului de agresivitate}

Identitățile sociale și noțiunile despre sine sunt strâns legate de instituțiile la care indivizii sunt afiliați (Lența \& Cormoş, 2017apud Blumer, 1956; Gubrium \& Holstein, 1997; Sartre, 1963). Astfel,indivizii găsesc scopuri și semnificații în cadrul instituțiilor și datorită faptului că pot să acceseze resurse simbolice sau materiale pentru a-și construi identități personale semnificante (Hinojosa, 2010 apud Holstein \& Gubrium, 2000).

Făcând referire la agresivitate se face automat trimitere la comportamentul agresiv și caracteristicle specifice acestuia. În acest context, agresivitatea poate fi definită ca „un ansamblu de conduite ostile manifestate fie conștient, fie inconștient ori fantasmatic în vederea distrugerii, degradării, constrângerii, negării sau umilirii cuiva sau a propriei persoane" (Gorgos, 1987).

Evidențiind potențialul acțiunilor agresive, comportamentele agresive pot fi grupate în agresivitiate antisocială, distructivă, îndreptată împotriva societății și agresivitate prosocială, care servește interesele comunității și ale persoanei (Lența \& Cormoş, 2017 apud Ranschburg 1978).

Mediul militar oferă celor care aderă la el resurse specifice care îi ajută pe aceștia să își construiască o identitate masculină ce poate fi caracterizată de: control emoțional, condiție fizică, autodisciplină, încredere în sine, atracție heterosexuală evidentă, posibilitatea de a folosi agresiunea și violența fizică și asumarea de riscuri; toate acestea reprezentând calități aliniate strâns mediului militar (Hinojosa, 2010 apud Higate, 2002, 2007).Pregătirea militarilor este asociată cu schimbări în ceea ce privește nivelul agreabilității. Astfel, s-a evidențiat că aceste schimbări odată survenite persistă prin manifestarea de către militari a unor niveluri din ce în ce mai scăzute de agreabilitate față de persoanele civile aflate în câmpul muncii. (Jackson et al. 2012)

În mediul militar nivelurile din ce în ce mai scăzute de agreabilitate se reliefează cu proponderență pornind de la regimul impus de rigorile mediului cazon, atmosfera din cadrul subunității, raportul de subordonare, renunțarea la o serie de drepturi și libertăți cetățenești, disponibilitatea necondiționată atunci când situația o 
impune. De asemenea, trebuie menționat căindivizii cu un nivel ridicat al agreabilității sunt mai înceți și șansele ca aceștia să reacționeze agresiv după ce au fost agresați sunt puțin probabile (Meier, Robinson, \& Wilkowski, 2006), în acest context un nivel redus al agresivității asociat cu un nivel crescut al agreabilității este justificat.

Așadar, presupunem că:

H1: Există diferențe statistic semnificative între militari și persoanele civile în ceea ce privește nivelul de agresivitate, militarii prezentând un nivel de agresivitate mai crescut decât persoanele civile.

\section{Autonomia personală în contextul activității profesionale}

Autonomia personală este o trăsătură de personalitate care, din punct de vedere al orientării generale în relațiile sale cu mediul,diferențiază individul în raport cu alții (Faiciuc, 2004).

Autonomia personală, ca trăsătură a personalității, constă în: capacitatea de autoderminare a individului; abilitatea sa de a lua decizii autonome cu privire la propria viață și în capacitatea acestuia de a materializa deciziile, prin inițiere, organizare, supervizare și revizuire a acțiunilor proprii, în absența controlului unor forțe externe sau a unor constrângeri, cu evaluarea opțiunilor existente și luând în considerare propriile interese, nevoi și valori. Pe de altă parte, mai constă și în sentimentul de dispunere a individului, în abilitatea de a face alegeri cu privire la direcția acțiunilor sale și de libertatea de a le finaliza (Albu, 2007). Autonomia personală crescută poate fi văzută și ca un grad ridicat de libertate și capacitate de deliberare neinfluențabilă și facilă, ca trăsătură psihică a conștiintei de sine și a personalității (Schiopu, 1997).

Autonomia personală, un construct multidimensional, extrem de disputat la nivelul specialiștilor, în ceea ce privește stabilirea unu consens cu privire la componența ei, este formată din cumulul a patru demensiuni, preluate (Russell şi Bakken, 2002), acceptate și operaționalizate în cadrul acestui studiu, după cum urmează: autonomie cognitivă, autonomie valorică, autonomie comportamentală și autonomie emoțională. 
- Autonomia cognitivă, cu referire la: procesul cognitiv, gândirea critică, capacitatea de a avea opini și idei proprii, capacitatea de a lua decizii asumate.

- Autonomia valorică conține prinicipiile, ideile și convngerile unei persoane, menținute indiferent de existența unor presiuni venite din partea societății.

- Autonomia comportamentală, definită prin capacitatea de acționa independent, în conformitate cu deciziile personale.

- Autonomia emoțională evidențiază existența capacităţii unei persoane de a-și forma și exprima emoțiile proprii, fără a se lăsa influențată de cei din jur.

În ceea ce privește militarii, Vest (2013) a evidențiat faptul că aceștia se percep ca o combinație dintre militar și persoană civilă, militarul fiind identitatea secundară ce devine dominantă în situații specifice. Militarii și persoanele civile coexistă și variază din punct de vedere al manifestărilor dominante, păstrarea acestora neimplicând o dificultate conștientă. Binomul militar-persoană civilă reprezintă o balanță care oscilează atât în detrimentul/beneficiul cetățeanului, cât și al militarului, având ca rezultat un total considerat format din părțile sale componente care le permite să se descrie singuri. Aspectul de interes nu îl reprezintă înclinarea balanței înspre un mediu sau altul, ci integrarea celor două componente de autoidentificare care nu coincid în permanență, putând uneori să deschidă și să modereze conflicte în perioadele în care există tranzit între ele.

Așadar, considerăm că:

H2: Există diferențe statisitic semnificative între militari și persoanele civile în ceea ce privește nivelul autonomiei personale, persoanele civile prezintând un nivel al autonomiei personale mai crescut decât militarii.

\section{Participanți și procedură}

\section{Metodă}

La acest studiu au participat 103 persoane dintre care, un grup de 50 de militari activi, 32 de bărbați și 28 de femei, cu o medie de vârstă de 26,10 ani, ofițeri și subofițeri, încadrați în Ministerul Apărării 
Naționale din România, dintre care 3 absolvenți de studii postliceale, 25 de absolvenți de studii de licență, 21 absolvenți de studii de masterat și un singur absolvent de studii doctorale. Dintre aceștia, doar 12 dețineau funcții de conducere la momentul completării chestionarelor.

Al doilea grup este format din 53 de persoane civile care își desfășoară activitatea în diferite sectoare ale mediului civil, fiind vorba de 24 de bărbați și 29 de femei, cu o medie de vârstă de 24 de ani, dintre care 13 absolvenți de studii liceale, un absolvent de studii postliceale, 29 de absolvenți de studii de licență, 8 absolveți de studii de masterat șiun singur absolvent de studii doctorale. Media de vârstăa a tuturor participanților la acest studiu este de 25,01 ani.

Administrarea a fost de tip creion-hârtie, fiind aplicată în grupuri mici, miliari și persoane civile.

\section{Instrumente}

ZKPQ (Zuckerman-Kuhlman Personality Questionnaire).

Acest chestionar a fost utilizat pentru stabilirea nivelului de agresivitate. Instrumentul măsoară cinci dimensiuni: căutarea impulsivă de senzații, sociabilitatea, neuroticismul-anxietatea, agresivitateaostilitatea și activitate, ultima dimensiune fiind cea de interes, scorată și interpretată. ZKPQ a fost adaptat în România de Adrian Opre (Opre D., Kiss, Opre A., 2004). Chestionarul cuprinde și o scală de dezirabilitate socială (Minciună sau Infrecvență), formată din 10 itemi, pentru a identifica răspunsurile nesincere.

ZKPQ conține 99 de itemi. Itemii chestionarului ZKPQ descriu modul: de acționare: „Nu obișnuiesc să arunc gunoi pe stradă."; de a simți: „Uneori mă simț tensionat și iritat."; de a gândi: "Adesea cred că oamenii pe care $\hat{\imath} i$ întâlnesc sunt mai buni decât mine."

Chestionarul AP (Atonomie Personală) a fost realizat de Monica Albu (Albu, 2007), măsurând autonomia personală pe patru dimensiuni: cognitivă, comportamentală, emoțională și valorică. AP conține un număr de 36 de itemi, fiecare descriind un anumit tip de comportament, corespunzător unei anumite dimensiuni ale autonomiei: autonomie cognitivă: „Dacă punctul meu de vedere este diferit de cel al majorităţii, înclin 
să cred că ceilalți au dreptate."; autonomie comportamentală: „Procedez cum cred eu că este mai bine, fără a ține cont de părerea celorlalți."; autonomie emoțională: "Îmi exprim sentimentele, chiar dacă cei din jurul meu nu îndrăznesc sau nu vor să şi le exprime."; și autonomie valorică: „Familia şi prietenii apropiați sunt cei care au o mare influență asupra felului în care aleg între bine şi rău."

\section{Rezultate}

În vederea testării primei ipoteze $\mathrm{s}$-a efectuat testul $\mathrm{t}$ pentru eșantioane independente. Probabilitatea asociată valorii calculate a testului $\mathrm{t}$ a fost $\mathrm{p}=.59>.05$, de unde rezultă că se acceptă ipoteza de nul și se afirmă că nu există o diferență semnificativă între cele două medii. Dat fiind aceast rezultat, se respinge prima ipoteză a studiului, putânduse afirma că, în cazul studiului de față, nu există diferențe semnificative statisitc între militari și persoanele civile în ceea ce privește nivelul lor de agresivitate.

Deși aceasta nu se confirmă, după cum relevă testul $t$ pentru eșantioane independente, din analiza cantitativă a mediilor răspunsurilor date, transformate în procentaje, care la rândul lor exprimă o proporție din punctajul maxim pe care l-ar fi putut obține, 17 puncte, echivalentul a $100 \%$ ca nivel maxim de agresivitate, se observă faptul că diferența dintre cele două eșantioane este de doar $2 \%$ în detrimentul persoanelor civile.

Tabel 1. Diferențe procentuale I2

\begin{tabular}{lcc}
\hline \multicolumn{1}{c}{ Media/Eșantion } & Militari & Persoane civile \\
\hline Media rezultatelor & & \\
obținute la chestionarul & $6.64=39,05 \%$ & $6.30=37,05 \%$ \\
ZKQP & & \\
$17=100 \%$ & & \\
\hline
\end{tabular}


Și pentru următoarea ipoteză $\mathrm{s}-\mathrm{a}$ efectuat testul $\mathrm{t}$ pentru eșantioane independente. Dată fiind valoarea lui $p=.09>.05$ rezultă că se acceptă ipoteza de nul și se afirmă că nu există o diferență semnificativă între cele două medii. În acest context, se respinge a treia ipoteză a studiului, afirmându-se că, în conformitate cu acest studiu, nu există diferențe semnificative statistic între militari și persoanele civile în ceea ce privește nivelul autonomiei personale.

Deși ipoteza anterioară nu a fost susținută de datele analizate, s-a realizat o analiză cantitativă a mediilor răspunsurilor date, transformate în procentaje, care la rândul lor exprimă o proporție din punctajul maxim pe carel-ar fi putut obține, 180 puncte, echivalentul a 100\% ca nivel maxim al autonomiei personale.

Tabel 2. Diferențe procentuale I4

\begin{tabular}{lcc}
\hline \multicolumn{1}{c}{ Media/Eșantion } & Militari & Persoane civile \\
\hline $\begin{array}{l}\text { Media rezultatelor generale } \\
\text { obținute la chestionarul AP }\end{array}$ & $135,32=75,28 \%$ & $130.86=72,7 \%$ \\
$180=100 \%$ & & \\
& & \\
\hline $\begin{array}{l}\text { Media rezultatelor autonomiei } \\
\text { cognitive }\end{array}$ & $35.76=79,46 \%$ & $34.22=76,04 \%$ \\
$45=100 \%$ & $41.04=74,61 \%$ & $38.81=70,56 \%$ \\
\hline $\begin{array}{l}\text { Media rezultatelor autonomiei } \\
\text { comportamentale }\end{array}$ & & \\
$\begin{array}{l}\text { 55=100\% } \\
\text { Media rezultatelor autonomiei } \\
\text { emoționale } \\
40=100 \%\end{array}$ & $28.26=70,65 \%$ & $27,49=68,72 \%$ \\
\hline $\begin{array}{l}\text { Media rezultatelor autonomiei } \\
\text { valorice } \\
40=100 \%\end{array}$ & $30.1=75,25 \%$ & $30.43=76,07 \%$ \\
\hline
\end{tabular}


În cazul autonomei cognitive obținerea unui punctaj de 45 de puncte prin răspunderea la itemii care măsoară această dimensiune este echivalentul a $100 \%$, ca nivel maxim al autonomiei cognitive. Se poate observa faptul că diferența dintre cele două eșantioane este de 3,42\% în detrimentul persoanelor civile.

Făcând referire la nivelul autonomei comportamentale obținerea unui punctaj de 55 de puncte prin răspunderea la itemii care măsoară această dimensiune este echivalentul a $100 \%$, ca nivel maxim al autonomiei comportamentale. Se poate observa faptul că diferența dintre cele două eșantioane este de $4,05 \%$ în detrimentul persoanelor civile.

La nivelul autonomei emoționale obținerea unui punctaj de 40 de puncte prin răspunderea la itemii care măsoară această dimensiune este echivalentul a $100 \%$, ca nivel maxim al autonomiei emoționale. Se poate observa faptul că diferența dintre cele două eșantioane este de doar $1,93 \%$ în detrimentul persoanelor civile.

Finalizând cu nivelul autonomei valorice, obținerea unui punctaj de 40 de puncte prin răspunderea la itemii care măsoară această dimensiune este echivalentul a $100 \%$, ca nivel maxim al autonomiei valorice. Se poate observa faptul că diferența dintre cele două eșantioane este de doar $0,82 \%$ în detrimentul militarilor.

Pentru evidențierea unor eventuale diferențe între cele două grupuri studiate la nivelul componentelor autonomiei personale, s-a efectuat testul t pentru eșantioane independente. S-a observat că există diferențe statistic semnificative în ceea ce privește autonomia comportamentală, în sensul că militarii au înregistrat un nivel mai ridicat spre deosebire de civili, $\mathrm{t}(101)=2.251, \mathrm{p}=.03$.

\section{Discuții}

Rezultatele au evidențiat inexistența unor diferențe semnificative statistic la nivelul agresivităţii și autonomiei personale în ceea ce privește militarii și persoanele civile. $\mathrm{Cu}$ toate acestea, s-au identificat diferențe în ceea ce privește o singură dimensiune a autonomiei personale, la nivelul autonomiei comportamentale, contrar ipotezei enunțate, rezultatele indicând un nivel mai ridicat al 
autonomiei comportamentale la militari, în comparație cu persoanele civile, care au participat la acest studiu.

Aceste descoperiri sugerează că militarii nu se diferențiază de persoanele civile din punct de vedere al agresivității, păstrând un nivel aproximativ similar cu cel al persoanelor civile. Mai mult, lipsa unei diferențe indică faptul că militarii, încadrați într-o armată neimplicată în război, dispun de un nivel de agresivitate controlat, disciplinat, care nu corespunde cu un nivel de agresivitate necontrolat, impulsiv. În această ordine de idei se poate emite ipoteza conform căreia reacțiile militarilor sunt controlate și direcționate în funcție de specificul activității pe care aceștia o desfășoară. Nediferențierea militarilor față de persoanele civile în ceea ce privește agresivitatea evidențiază o bună integrare a acestora în societatea civilă, dar și controlul exercitat de sistemul militar asupra personalităţii militarilor, unde exprimarea emoțiilor și a răbufnirilor nu prezintă tolerare, motiv pentru care mascarea/inhibarea lor, ca mecanism de protecție, este absolut necesară.

În ceea ce privește diminuarea comportamentelor agresive și violente, autocontrolul, ce poate fi exprimat prin intermediul unui nivel crescut al autonomiei personale, este un determinant important în reducerea comportamentelor agresive și violente (Van Lange, Rinderu\& Bushman, 2017).

Făcând referire la nivelul autonomiei personale și la faptul că nu a reieșit, din demersurile efectuate, existența unor diferențe între militari și persoanele civile, se sugerează faptul că militarii, chiar dacă prin natura funcției lor sunt obligați să cedeze din autonomia lor personală în favoarea regulamentelor militare, unde cel mai mare în grad și funcție dispune de cea mai mare autoritate și a ordinelor ce trebuie executate, indiferent de poziționarea personală/polaritatea afectivă față de acestea, dispun de un nivel similar al autonomiei personale celui al persoanelor civile. Prin urmare, deși militarii respondenți sunt de minim 4 ani încadrați în forțele armate, nu evidențiază un nivel al autonomiei personale mai scăzut, așa cum s-a presupus inițial, ba din contră, evidențiază un nivel al autonomiei comportamentale mai ridicat decât cel al persoanelor civile, sugerând prin aceasta o asumare mai crescută a propriilor acțiuni și un discernământ mai mare din punct de vedere al principiului acțiunii și reacțiunii propriilor fapte. În această ordine de 
idei, sistemul militar, contrar aparențelor, prin condițiile specifice de desfășurare a activităților nu produce modificări în natura personalității de factură să scadă independența individului în detrimentul regulamentelor și ordinelor, ci responsabilizează militarul și îl determină să ị̂i asume comportamentele și consecințele acestuia. Astfel, un nivel al autonomiei comportamentale mai ridicat și lipsa diferențelor la nivelul celorlalte trei dimensiuni ale autonomiei persoanle: autonomia cognitivă, autonomia valorică și autonomia emoțională certifică de asemenea, o bună integrare a militarilor în societatea civilă și o asumare mai mare a conduitelor lor, mediul militar fiind premisa care conferă această caracteristică, prin autonomia lor înțelegându-se "comportamentul indivizilor care nu ascultă decât de legi pe care şi leau dat ei înşişi sau de legi cărora le-au înțeles şi acceptat valoarea" (Piéron, 2001). Deși autonomia presupune a stabili scopuri şi a acţiona fără a fi supus controlului extern sau constrângerilor, nivelul ridicat al autonomiei militarilor poate fi explicat prin asumarea de către aceștia a valorilor și simbolurilor naționale și ostășești, aceștia interiorizând primirea și executarea ordinelor, precum și respectarea strictă a regulamentelor militare drept datorii morale și stări de fapt ce trebuie să existe, justificate pe deplin în mediul militar.

Este posibil ca lipsa diferențelor în ceea ce privește nivelul agresivității între militari și civili să fie explicată de un mediu militar care nu este implicat în acțiuni de război, aflat pe timp de pace, care are ca principale activități executarea de simulări și exerciții militare.

Thomas et al. (2010) a evidențiat că un procent cuprins între 8,5\% și 14\% dintre soldații americani care se întorc din teatrele de luptă din Irak și Afganistan suferă de tulburarea posttraumatică (PTSD) și de depresie cu deficiențe funcționale grave, iar un procent între 23\% și 31\% suferă unele deficiențe, în timp ce la aproape jumătate dintre soldați s-a remarcat apariția abuzului de alcool și de comportamente agresive.

În aceste condiții trebuie să se țină cont de faptul că militarii care se confruntă cu traume în urma implicării în lupte sunt predispuși să dezvolte PTSD și în același timp să facă abuz de alcool, numărul expunerilor la situațiile de luptă fiind corelat pozitiv atât cu abuzul de alcool, cât și cu comportamentul agresiv (Kaikkonen \& Laukkala, 2016), iar militarii care suferă de PTSD în același timp sunt dependenți de 
alcool, înregistrând un nivel ridicat de agresivitate (Kaikkonen \& Laukkala, 2016 apud Souza et al., 2011).

Rata de manifestare a PTSD-ului la militarii care au participat la misiuni timp de 12 luni este semnificativ mai mare decât a militarilor care au participat la misiuni de 3 luni, efectele fiind și ele proporționale cu durata misiunii, astfel între 8,8\% și 14\% dintre militari au prezentat afecțiuni funcționale serioase datorită PTSD-ului sau simpotmelor depresiei. Consuml de alcool sau comportamentul agresiv reprezintă un factor comun, întrucât aproximativ $50 \%$ din militarii care prezintă simptomele depresiei sau ale PTSD, prezintă și unul sau ambii dintre factorii comuni (Castro \& Hoge, 2010).

Însă, este de asemenea posibili, ca militarii, dat fiind nivelul lor ridicat de autonomie comportamentală, în comparație cu persoanele civile, să recunoască consecințele nefaste ale unui comportament agresiv și să evite conștient manifestarea lui. În acest context, se identifică o dimensiune preventivă a militarilor care le poate asigura chiar și supraviețuirea în cadrul unui mediu ostil.

$\mathrm{Nu}$ în ultimul rând, este cunoscut faptul că, nivelul de agresivitate este influențat de dimensiunea grupului și de orientările acestuia, individul acționând în interiorul grupului diferit față de modul individual (Hogg, 2016), existândastfel șanse ca nivelul de agresivitate și autonomie măsurat indiviual să fifost diferit, dacă ar fi fost măsurat la nivelul grupului, atât la militari, cât și la persoanele civile.

\section{Limitele și direcții viitoare}

Generalizarea rezultatelor la nivelul populațiilor de referință este discutabilă, dat fiind faptul că selectarea persoanelor care să răspundă la chestionar s-a făcut în funcție de opțiunea și disponibilitatea acestora, neexistând un procedeu de selecție randomizat, aspect care poate constitui o amenințare la adresa validității interne.

De asemenea, integrarea în cadrul mediului civil a oricăror persoane care nu fac parte dintr-un mediu militarizat poate constitui o limitare în ceea ce privește generalizarea rezultatelor, întrucât diversitatea componentelor mediului civil este atât de mare în comparație cu cele ale mediului militar, încât diferențele dintre cele două grupuri sunt dificil de intendtificat și atribuit în același timp. 
Există sugestia ca pe viitor, mediul civil să fie mai bine încadrat în limite, eventual comparația dintre nivelurile constructelor vizate să se realizeze între populații clar definite și delimitate conceptual, ca de exemplu între militari și avocați.

Dat fiind faptul că eșantionul militarilor a fost compus cu preponderență din ofițeri, soldații, maiștrii militari și subofițerii fiind reprezentați de un număr mic de respondenți sau chiar nereprezentați, este posibil ca rezultatele obținute în cadrul acestui studiu să nu fie reprezentative pentru întreaga populație a militarilor, ci pentru populația ofițerilor din cadrul mediului militar. Dat fiind faptul că studiul a avut carepondenți cetățeni români, generalizarea rezultatelor poate fi făcută doar la nivelul acestei țări, întrucât fiecare armată are specificul propriu în ceea ce privește cultura internă și formarea militarilor care o compun.

Studiul de față s-a realizat prin chestionarea unor militari aflați în stare de pace, neimplicați în situați combative, care să evidențieze specificul activității. În acest context, trebuie diferențiat între o armată de pace și o armată de razboi. În primul rând armata de pace prin excelență presupune pregătirea permanentă a forțelor deținute în vederea operaționalizării acestora în cazul apariției unor amenințari pe care le are în atenție la adresa statului din care face parte. $\mathrm{Cu}$ toate acestea armata de pace își desfășoară activitatea într-un mod organizat după un program orar pe care militarii trebuie să îl respecte, dar care le permite acestora un contact permanent cu mediul civil și o interacțiune deplină cu societatea. Trecând în polul opus, armata de război presupune funcționarea după reguli stricte, programul orar al militarilor fiind controlat în proporție de $100 \%$, exigențele și cerințele comandanților fiind mult mai drastice, concomitent $\mathrm{cu}$ consecințele nerespectării întocmai a ordinelor. Rezultatele obținute la acest studiu relevă nivelul de agresivitate și al autonomiei persoale al unor militari care își desfășoară activitatea într-o armată de pace, însă se pune problema păstrarii acestor niveluri și în cazul unei armate de război, aspecte nesurprinse în cazul de față.

Cercetările viitoare care abordează posibilele diferențe între militari și persoanele civile la nivelul unor constructe de tipul autonomiei persoanele sau agresivității ar trebui să recolteze datele de la 
eșantioane construite în mod randomizat, care să includă toate categoriile populațiilor de referință, pentru a realiza o reprezentativitate cât mai mare.

De asemenea, o posibilă direcție viitoare, și totodată continuare a acestui studiu ar consta în introducerea unei variabile moderatoare care să accentueze/diminueze nivelul agresivității, pentru a studia dacă efectele la nivelul celor două populații diferă.

Considerând existența unor diferențe incontestabile între o armată aflată în război și una pe timp de pace, premisa conform căreia armata pe timp de pace se aseamană mai mult cu mediul civil este una susținută de studiul de față. Însă, o altă posibilă direcție de aprofundat pe viitor o constituie compararea nivelurilor constructelor investigate în acest studiu, agresivitatea și atuonomia personală, prin realizarea unui studiu longitudinal în care să fie măsurate constructele vizate la militarii români înainte de a pleca în misiune de luptă pentru menținerea păcii în teatrele de operații, care presupune participarea la război, și în timpul misiunilor de luptă.

\section{Bibliografie}

Albu, M. (2007). Un nou instrument pentru evaluarea autonomiei personale la adolescenti. Anuarul Institutului de Istorie "George Bariț" din Cluj-Napoca, Seria Humanistica, V, p. 113-130.

Castro, C. A., Hoge, C. W. (2010). Prevalence of Mental Health Problems and Functional Impairment Among Active Component and National Guard Soldiers 3 and 12 Months Following Combat in Iraq. Archives of General Psychology, 67(6).

Faiciuc, L. (2004). Autonomia comportamentala: definire și căi de dezvoltare. În Cercetări și aplicații în psihologie, Timișoara: Editura Augusta și Artpress.

Gorgos, C. (1987). Dicționar enciclopedic de psihiatrie. București: Editura Medicală.

Hinojosa, R. (2010). Doing hegemony: Military, men, and constructing a hegemonic masculinity. The Journal of Men's Studies, 18(2), 179194. 
Hogg, M. A. (2016). Social identity theory. Cham: Springer.

Jackson, J. J., Thoemmes, F., Jonkmann, K., Lüdtke, O., Trautwein, U. (2012). Military Training and Personality Trait Development: Does the Military Make the Man, or Does the Man Make the Military? Washington University in St. Louis and University of Tübingen.

Kaikkonen, N. M., \& Laukkala, T. (2016). International military operations and mental health. Nordic Journal of Psychiatry, 70(1), 10-15.

Lența, O. E., \& Cormoș, V. C. (2017). Aggression and Violence, Corrosive Factors of Humanity. Postmodern Openings/Deschideri Postmoderne, 8(1).

Lomsky-Feder, E., Gazit, N., \& Ben-Ari, E. (2008). Reserve soldiers as transmigrants: Moving between the civilian and military worlds. Armed Forces \& Society, 34(4), 593-614.

Opre D., Kiss F., Opre A. (2004). Scala căutării de senzații: aplicabilitate transculturală. Noi tendințe în psihologia personalitătii. Diagnoză cercetare aplicații Vol II. Cluj Napoca: Editură ASCR.

Russell, S. T., \& Bakken, R. J. (2002). Development of autonomy in adolescence. Cooperative Extension, Institute of Agriculture and Natural Resources, University of Nebraska-Lincoln

Șchiopu U. (coord.). (1997). Dicționar de psihologie. București: Editura Babel.

Thomas, J. L., Wilk, J. E., Riviere, L. A., McGurk, D., Castro, C. A., \& Hoge, C. W. (2010). Prevalence of mental health problems and functional impairment among active component and National Guard soldiers 3 and 12 months following combat in Iraq. Archives of General Psychiatry, 67(6), 614-623.

Van Lange, P. A., Rinderu, M. I., \& Bushman, B. J. (2017). Aggression and violence around the world: A model of CLimate, Aggression, and Self-control in Humans (CLASH). Behavioral and brain sciences, 40 .

Vest, B. M. (2013). Citizen, soldier, or citizen-soldier? Negotiating identity in the US National Guard. Armed Forces \& Society, 4, 602627. 